\title{
Chemical Analysis of Birch Tree (Betula pendula Roth) Degraded by Fungus
}

\author{
Osman Camlibel * \\ The aim of this study was to investigate degraded birch trees (Betula \\ pendula Roth) that suffered from a harmful fungus called Piptoporus \\ betulinus. The main chemical analysis of $B$. pendula degraded by the \\ fungus, included the holocellulose, alpha-cellulose, and lignin contents \\ and was determined in cold and hot water and alcohol-benzene solubility \\ in $1 \% \mathrm{NaOH}$ mixtures. This fungus caused $B$. pendula to lose mass and \\ chemical properties. The declining amount of holocellulose mass loss was \\ $6.7 \%$ according to the holocellulose test. This decrement caused the \\ quality of the birch holocellulose to decline. The total loss difference was \\ $9.8 \%$ according to the alkaline solubility analysis of the $1 \% \mathrm{NaOH}$ test and \\ $14.3 \%$ according to the density analysis of the test. The loss difference \\ was $4.2 \%$ according to the alcohol-benzene analysis of the test.
}

Keywords: Betula pendula Roth; Birch tree; Mass loss; Wood degradation; Chemical analysis

Contact information: Department of Material and Material Processing, Kirikkale Vocational School, Kırlkkale University, Kırlkkale, Turkey; *Corresponding author: osmancamlibel@kku.edu.tr

\section{INTRODUCTION}

Although Turkey has 20 million hectares of forest areas, which is roughly $27 \%$ of the country's land area, wood biomass is not used efficiently enough and the demand for raw materials increases the need for wood-based products (Karayılmazlar et al. 2011). Betula pendula Roth is the most important forest tree and is imported from the north-west district of Ukraine (Hynynen et al. 2010).

Betula pendula is known as a white birch wood and is classified in the mature trees group. The air mass specific gravity of B. pendula is $0.62 \mathrm{~g} / \mathrm{cm}^{3}$ (Çakıroğlu et al. 2011). The mean dry density of $B$. pendula ranges from 0.480 to $0.550 \mathrm{~g} / \mathrm{cm}^{3}$ (Heräjärvi 2001). The mechanical resistance of $B$. pendula is low but its physical strength properties are good. It is an easily processable wood. However, $B$. pendula timber undergoes cracking and deformation in dry open air. It is weak in open air and immediately decays. Therefore, this type of wood is more widely used for aesthetic and design purposes.

The biological degradation of lignocellulosic materials, especially woody biomass (all lignocellulosic materials) by wood-rot fungi basidiomycetes, acts as a necessary act in the carbon circle. Holocellulose is an important carbon/energy resource for the growing of many fungi. Brown rot fungi are perhaps the most important agents involved in the biodegradation of all lignocellulosic materials (Arantes and Goodell 2014).

The first attack by the brown rot fungi degradation includes cleavage of glycosidic bonds, depolymerization of wood polysaccharides, and degradation of pectic substances. Correspondingly, intramolecular hydrogen bonding within cellulose is reduced, while the presence of phenolic groups is increased (Arantes et al. 2012). Arantes and Goodell (2014) have studied the brown-rot-fungi biochemical operation step related to the biodegradation of lignified herb of yearly cell walls. 
Incipient brown-rot fungus processes are localized in outer cell wall regions allocated with the middle lamellae, primary cell walls, and outer secondary cell walls. Despite this, white-rot fungus processes are evenly distributed in the tracheid cells, even if the cells in one thin section are affected to very different extents (Fackler et al. 2012).

Cellulose is the basic structural component of the plant cell wall, as well as being the most plentiful polysaccharide on Earth. Cellulose is an important renewable biological material. Basidiomycetous fungi are among the most important degraders of wood because numerous basidiomycetous fungi grow on dead wood or litter, an environment that is rich in cellulose (Baldrian and Valaskova 2008). The fungal attack is liable for important reductions in mechanical and physical of wood properties, and it has effects on moisture content, electrical conduction acoustics, convection, elasticity, and plasticity in wood (Cowling 1961; Schmidt 2006).

Piptoporus betulinus grows equally well on heartwoods of sycamore, basswood, and birch, on sapwoods of white oak, butternut, and osage orange, and on white portions of red cedar wood (Lafuze 1937). Sporophores of the birch fungus Piptoporus betulinus have only been observed on species belonging to the Betula genus (Henningsson 1965). Fagus sylvatica L. (beech) wood block has been degraded under laboratory conditions by the white-rot fungi (Trametes versicolor, Pleurotus ostreatus, and Lentinus edodes). The weight loss amounts of the wood block of Fagus sylvatica were 51, 27, and 24\%, respectively (Faix et al. 1991). The most important wood decaying fungi are the brown rot fungi. Brown rot fungi degrade wood polysaccharides while partially changing the lignin. As a result of this kind of decay, the wood shrinks, shows a brown discolouration owing to oxidized lignin, and cracks into roughly cubical pierces (Gilbertson 1980; Monrroy et al. 2001).

Living B. pendula is weak and affected by the fungus. After the tree dies, the decaying continues in the wood core and bark. Pine sap-wood blocks were exposed to brown-rot fungi for 1, 2, 3, and 4 months by Irbe et al. (2006). According to the results, the most notable feature is the preferred degradation of mannose both by brown-rot fungi $(P$. placenta with $80.9 \%$ weight loss) and brown-rot fungi ( $C$. puteana with $77.5 \%$ weight loss) in comparison to the reference. Kahl et al. (2017) indicated that fungi, beetles, and enzymes play important roles for wood decomposition. According to the study, a mix of different tree species in deadwood enrichment strategies might be most effective for promoting species diversity in the degrading organisms.

Lachowicz et al. (2019) have studied a set of collected test samples of silver birch (Betula pendula) from different forest regions of Poland. They suggested optimization of traditional methods and the development of new ecological methods. According to new methods, comprehensive results and knowledge concerning the variability in the chemical composition of silver birch wood (solubility in water and ethanol, ash content, cold water, hot water, $1 \% \mathrm{NaOH}$, contents of cellulose, lignin, pentosans, $\mathrm{pH}$ value) depending on the forest habitat type and the location of the forest stand may have a meaningful impact on the more rational and economic use of this valuable industrial wood.

Higher Basidiomycota have been used in natural drugs throughout the world for hundreds of years. Fomitopsis betulina (previously Piptoporus betulinus) is an example of this kind of fungi, which give rise to brown rot of birch wood (Pleszczynska et al. 2017). In natural earth, wood undergoes biological decay, firstly by white rot fungi, brown rot fungi, and soft rot fungi. Basidiomycetes have responsibility for the majority of wood decay, for instance mass loss and strength loss (Eriksson et al. 1990; Zabel and Morrell 1992; Mohebby 2003; Schmidt 2006). Schmidt et al. (2012) collected samples of infected 
trees living in the city, which included fruit bodies of wood decay fungi. They researched causal agents of wood rot. Song et al. (2012) determined that a competitive mutual effect between fungal species can promote colonization and that this can have an important result on the conclusion of wood degradation.

The B. pendula tree is common in Europe, Asia, and America. Annual white to brownish fruiting bodies of the species can be found on trees in the northern hemisphere (Pleszczynska et al. 2017). Arantes and Goodell (2014) studied the current understanding of brown-rot fungal biodegradation mechanisms.

The work of Valaskova and Bandrian (2006) shows that $P$. betulinus fungi perform fast hydrolysis of lignocellulose due to their hydrolytic enzymes with relatively expansive substrate specificities. Ujangr (1993) investigated the ratio and percentage of weight loss caused by decay of white-rot and brown rot fungi. According to study, average losses were is the range 27.6 to $34.4 \%$ due to the fungi. Brown rot fungi affect all softwoods, where it degrades both hemicellulose and cellulose but leaves lignin intact as a residue (Wong and Wilkes 1988; Rayner and Boddy 1988). Van der Wal et al. (2015) have shown that wood moisture content contributed particularly to promoting sap-wood decay in early decay phases, whereas fungal community composition and species riches were the best determinative for mass loss in the later stages.

The forests of Turkey alone are not enough to supply the increasing demand of raw materials needed for wood-based products. $B$. pendula is used as the raw material in woodbased products. $B$. pendula wood has a deteriorated structure and mass loss after being biologically affected by fungi. Moreover, this fungus affects the living trees in the forest. In the present paper, the author shows the analysis results of the degraded B. pendula wood. This study considers the product productivity and the in-production cost calculation of wood-based products.

\section{EXPERIMENTAL}

\section{Chemical Usage}

Chemical formula, CAS number, molecular weight of chemicals used in chemical analysis were as follows: Sodium Chlorite CAS number. 7758-19-2, chemical formula: $\mathrm{ClNaO}_{2}$, molecular weight: 90.44g/mol. Benzene: CAS number: 71-43-2. chemical formula: $\mathrm{C}_{6} \mathrm{H}_{6}$, molecular weight: $78.11 \mathrm{~g} / \mathrm{mol}$. Sulfuric acid; CAS number: 7664-93-9. chemical formula: $\mathrm{H}_{2} \mathrm{SO}_{4}$, molecular weight: $98.079 \mathrm{~g} / \mathrm{mol}$ Sodium hydroxide: CAS Number:1310-73-2. chemical formula: $\mathrm{NaOH}$. Molecular weight:39.997g/mol.

\section{Materials}

The biodegraded Betula pendula woods were imported from (Sunrise Company, Western Carpathian Region, Ukraine) Ukraine to Turkey by ship. The diameters and the lengths of the control and degraded $B$. pendula ranged from 10 to $15 \mathrm{~cm}$ and 75 to $100 \mathrm{~cm}$, respectively. Figure 1 shows the forest map of Ukraine.

Piptoporus betulinus is a brown-rot fungus. This fungus only uses weak, old, dead trees as hosts (Lee et al. 2010). Henningsson (1965) reported that as a result of $P$. betulinus attacking birch wood under favourable conditions, a maximum weight loss of up to approximately $71 \%$ occurs. Valaskova and Baldrian (2006) reported that it causes a fast mass loss of birch wood or other lignocellulose substrates. 


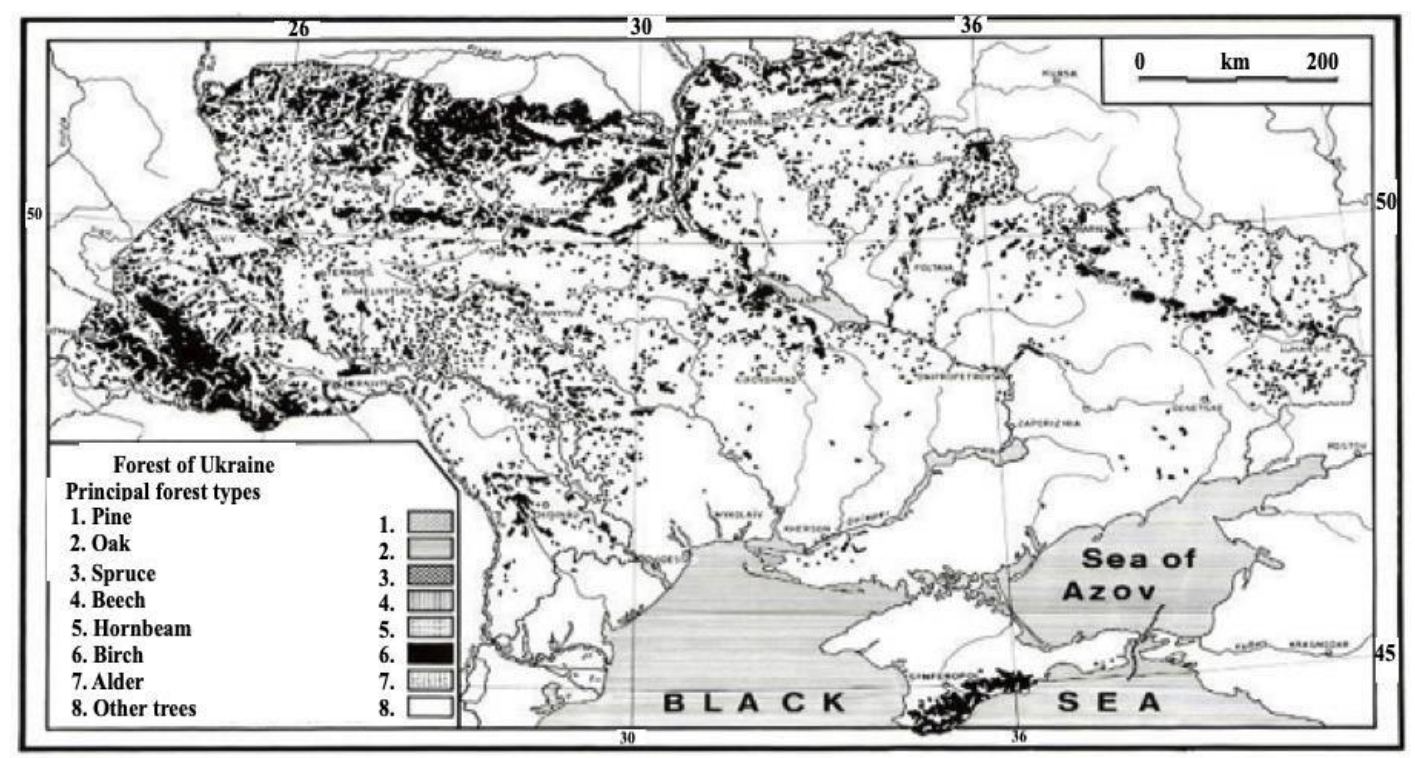

Fig. 1. Distribution map of Betula pendula species in Ukraine Forest; this map was acquired from the Forest in the Internet Encyclopedia of Ukraine database

Baldrian and Gabriel (2002) explained that this fungus species is a hardwoodspecific parasite of Betula pendula (Betula spp.) trees in northern temperate forests and causes a fast wood decay. It is also one of the most common brown-rot species in Central Europe. Bell and Burnett (1966) reported that it can depolymerize cellulose.

Ujangr et al. (2007) reported the weight loss for 60 days in the mini test block of Betula pendula $(1 \mathrm{~cm} \times 3 \mathrm{~cm})$ timber in their study. According to the research, they were decayed with soft-rot fungi (Chaetomium globosum), white-rot fungi (Corilous versicolor), and brown rot fungi (Coniophora putana). As a result of the research, soft rot fungi (Chaetomium globosum) caused $45.5 \%$ mass loss, white rot fungi (Coriolous versicolor) caused $35.4 \%$ mass loss, and brown rot fungi (Coniophora putana) caused $29.5 \%$ mass loss.

In this study, chemical compounds and the mass losses of the biodegraded $B$. pendula wood were analyzed by chemical methods.

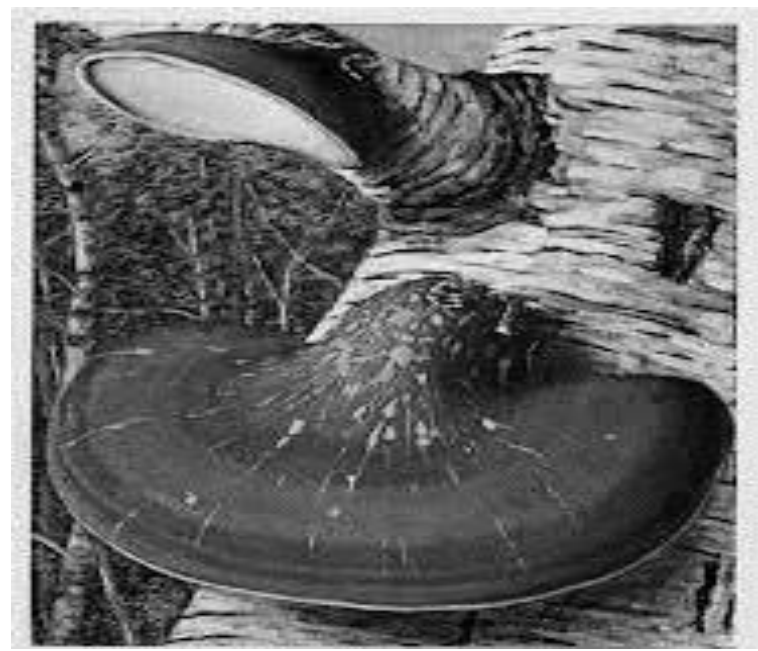

Fig. 2. Piptoporus betulinus fungus on trunk of Betula pendula tree 


\section{Methods}

The density analysis

This analysis was performed according to the TS EN 323 (2008) standard. The experimental results are given in Table 1. The analyzed samples are shown in Fig. 3.

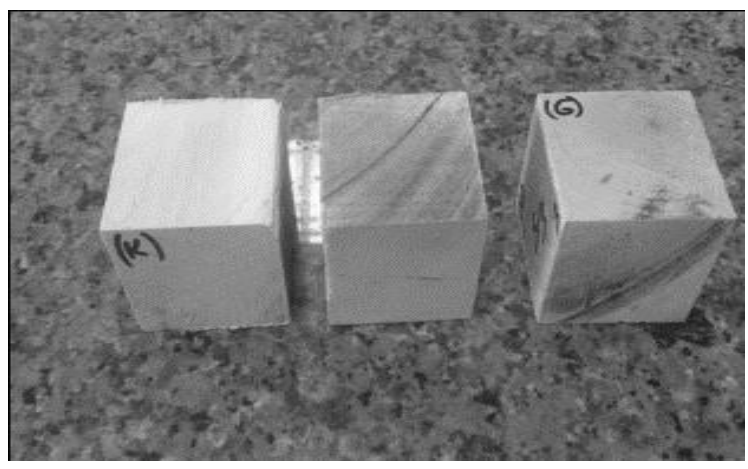

Fig. 3. Betula pendula density analysis sample

The chemical analysis

The wood chips samples ranged from 1.8 to $2.0 \mathrm{~cm}$ in length and from 2 to $3 \mathrm{~mm}$ in thickness. The samples are shown in Fig. 4.

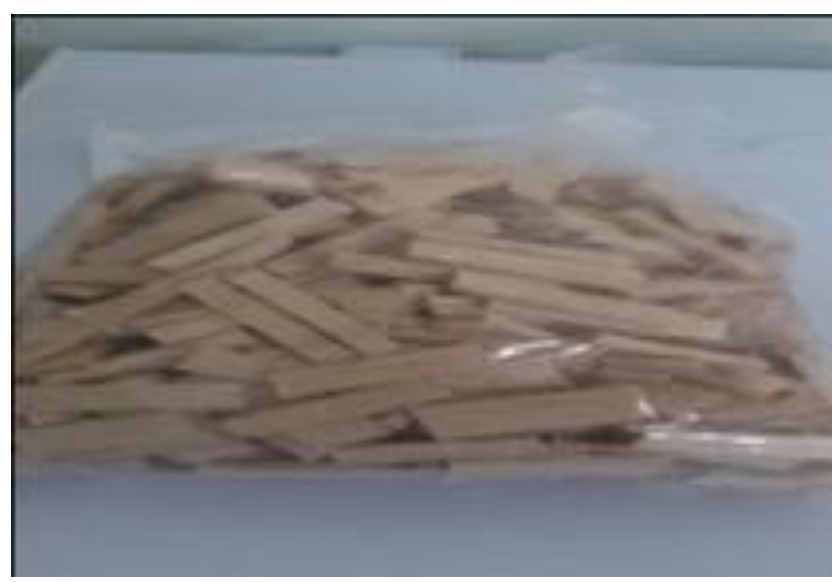

Fig. 4. Betula pendula chips for chemical analysis

The chemical analysis measurements were performed according to TAPPI T257 cm-02 (2012). The materials were milled using a laboratory-type Wiley Retsch SM 100 mill (Haan, Germany). The ground wood particles were sieved (40- to 60-mesh). The coarse portions were sieved through 40-mesh sieve, and the fine portions were sieved through 60-mesh sieve. Therefore, the remaining parts on the 60-mesh screen were used for testing purposes as per the TAPPI T257 $\mathrm{cm} 02$ (2012) standard. The remaining particles in the sieve were collected and placed into a glass jar, and the jar lid was closed. The moisture of the test samples was equalized at $105 \pm 3{ }^{\circ} \mathrm{C}$ as per the TSE TS 2471 (1976) standard. The preparation of test samples for chemical property detection was completed according to the following standards: for holocelluloses, the Wise Chlorite Method (Wise et al. 1946), alpha-cellulose as per TAPPI T203 cm-99 (1999), lignin as per TAPPI T222 om-11 (2006), alcohol-benzene as per TAPPI T204 om-88 (2002), 1\% NaOH as per TAPPI T212 om-02 (2002), and hot-cold water as per TAPPI T207 cm-99 (1999). The prepared samples are shown in Fig. 5. 


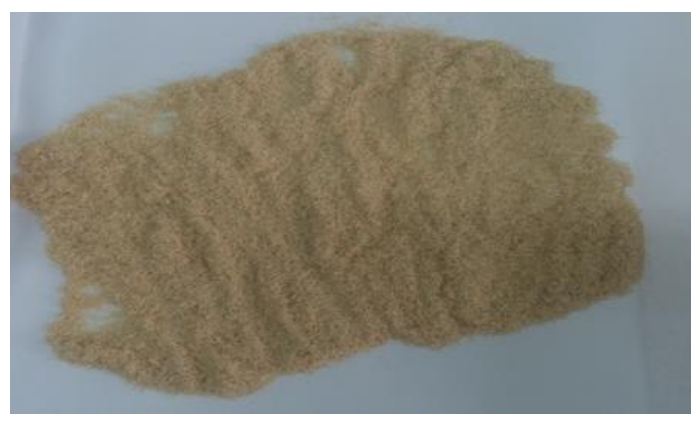

Fig. 5. Betula pendula samples prepared for chemical analysis

The chemical analyses were performed in the chemistry laboratory of Duzce University Forestry Industrial Engineering (Düzce, Turkey).

\section{Holocellulose Analysis}

Holocellulose can be defined as the total of hemicellulose and cellulose contents. The extractives materials, lignin, and cellulosic compounds were removed from the medium to insulate the holocellulose from the biomass birch materials. The holocellulose content was estimated using Wise et al. (1946) methods and the alpha-cellulose contents were determined using the TAPPI T203 cm-99 (1999) standard.

Alpha-cellulose analysis

Alpha-cellulose has the highest degree of polymerization in cellulose-containing compounds. The TAPPI T203 cm-99 (1999) standard was used in this analysis method. Figure 6 shows the alpha-cellulose of Betula pendula.

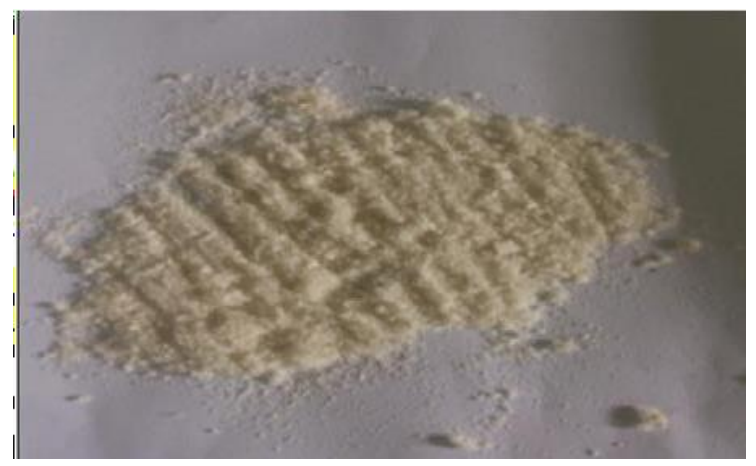

Fig. 6. Alpha cellulose of Betula pendula

\section{Lignin analysis}

Lignin is the main component of woods. Each type of wood has a different lignin content. Lignin analysis was performed according to TAPPI T222 om-11 (2006), and the ash analysis was performed according to TAPPI T211 om-02 (2002).

\section{Alcohol-benzene analysis}

The purpose of this analysis was to determine the proportion of components, such as oil, paraffin material, resin, and tannin. In this analysis, the TAPPI T204 om-88 (2002) standard was applied. 
$1 \%$ Sodium hydroxide solubility for mass loss of wood

This test method determines the solubility of wood in a hot diluted alkali solution $1 \%$ sodium hydroxide $(\mathrm{NaOH})$ solution. In this analysis, Betula pendula determines the degree of fungus decay of a pendula wood in a particular wood sample. As the wood decays, the percentage of alkali-soluble material increases. The pulp caused by the decay increases in proportion to the decrease in yield. This method was used to determine the degree of biomass loss due to fungal rot or deterioration. TAPPI T212 om-02 (2002) was used in this test.

\section{Hot-cold water solubility}

The inorganic salts, sugars, polysaccharides, and phenolic materials were dissolved in this test. The TAPPI207 cm-99 (1999) standard was used.

\section{RESULTS AND DISCUSSION}

\section{Density Loss Measurement of Betula pendula}

The density loss of the Betula pendula wood, the density results of the control wood, and the results of the biodegradable wood by the fungus are given in Table 1. In this method, TSE TS 2471 (1976) and TS EN 323 (2008) standards are applied.

Table 1. Density Analysis of Betula pendula at Oven-dry Moisture

\begin{tabular}{|c|c|}
\hline Samples & Density $\left(\mathrm{g} \mathrm{cm}^{-3}\right)$ \\
\hline Control Betula pendula & 0.552 \\
\hline Degraded Betula pendula & 0.474 \\
\hline Density loss (\%) & 14.13 \\
\hline
\end{tabular}

The difference between the density of biodegraded wood by Piptoporus betulinus fungus and the control wood density were calculated as $14.1 \%$. The oven densities of both $B$. pendula control and degraded B. pendula woodwere calculated according to TS EN 323 (2008) standard. As a result of this analysis, degraded Betula pendula wood exhibited $14.1 \%$ mass loss by fungi. Analysis of degraded B. pendula holocellulose was performed according to the TAPPI om-02 (2002) standard. The loss of holocellulose was $6.7 \%$. Curling et al. (2002) reported that the changes cause important losses in mechanical properties before measurable weight loss can be detected.

Fungus consumed only holocellulose in B. pendula wood. Brown rot fungi are important well-defined groups cellulose-degrading fungi (Arantes and Goodell 2014). Piptoporus betulinus is a general wood rotting fungus parasitic for birch (Betula species). İt gives rise to fast mass loss of birch wood or other lignocellulose substrates (Valaskova and Bandrian 2006).

\section{Chemical Analysis}

The results of chemical analysis of alcohol-benzene extractive, hot-cold water, and $1 \% \mathrm{NaOH}$ solubility are shown in Table 2. Equations 1 and 2 were used to obtain the values in Table 2,

$$
\%=((\mathrm{A}-\mathrm{B}) / \mathrm{A}) \times 100
$$


where $A$ is the oven dry weight of the specimen before extraction and $B$ is the oven dry weight of the specimen after extraction, $g$.

$$
\text { Numerical difference of this analysis }=(x-y)
$$

where $x$ is the control $B$. pendula wood specimen and $y$ is the degraded B. pendula wood specimen.

Table 2. Chemical Analysis of Betula pendula

\begin{tabular}{|c|c|c|c|c|c|c|c|c|c|}
\hline \multirow{2}{*}{ Chemical Analysis } & \multicolumn{3}{|c|}{$\begin{array}{c}\text { Alcohol-benzene } \\
\text { Extractive (\%) }\end{array}$} & \multicolumn{3}{|c|}{$\begin{array}{l}\text { Hot-cold Water } \\
(\%)\end{array}$} & \multicolumn{3}{|c|}{$1 \% \mathrm{NaOH}$} \\
\hline & A $(g r)$ & B $(g r)$ & $\%$ & A $(g r)$ & $B(g r)$ & $\%$ & A $(g r)$ & B (gr) & $\%$ \\
\hline Control Wood (x) & 4.00 & 3.87 & $3.17 \%$ & 2.00 & 1.95 & $2.25 \%$ & 2.00 & 1.67 & $16.20 \%$ \\
\hline Degraded Wood (y) & 4.00 & 3.83 & $4.02 \%$ & 2.00 & 1.87 & $6.45 \%$ & 2.00 & 1.48 & $26.00 \%$ \\
\hline Result & & & $0.85 \%$ & & & $4.20 \%$ & & & $9.80 \%$ \\
\hline
\end{tabular}

A: Weight before analysis, B: Weight after analysis

As shown in Table 2, fungi could reduce mass loss resistance in Betula pendula wood percent $10 \%$. This reduction indicates capability of the fungi to attack wood aggressively. According to Kubick (2013), separated ether bonds in cellulose are liable for decreases in strength.

The result of the alcohol-benzene extractive was measured as $3.17 \%$ for the control samples of Betula pendula. The biodegraded woods by fungus was measured as $4.02 \%$. Thus, the numerical difference of this analysis was $0.85 \%$. Therefore, degraded wood quality was less than the control wood. The result of hot-cold water solubility of the $B$. pendula control sample was measured as $2.25 \%$. Therefore, the biodegraded wood by fungus was $6.45 \%$. Thus, the numerical difference of this analysis was measured as $4.20 \%$. Therefore, the analysis of biodegraded wood compared to the control wood increased more than measured. It can be seen that the strength of the biodegraded wood decreased. According to the result of $1 \% \mathrm{NaOH}$ analysis, $B$. pendula control, and decayed wood was decreased by 1.67 and $1.48 \mathrm{~g}$ of wood mass, respectively. The $B$. pendula control sample was measured as $16.2 \%$ as a result of $1 \% \mathrm{NaOH}$ solubility. Biodegraded woods caused by fungus were $26.0 \%$. Thus, the degradation degree of degraded wood was determined as $9.8 \%$. The $1 \% \mathrm{NaOH}$ test describes the degradation degree of biomass. The alkali solubility increased as the fungus decay increased in wood. The results of chemical analysis of holocellulose and lignin for B. pendula are shown in Table 3.

Boddy (2001) reported that white rot fungi are the only organisms known to be able to completely decompose lignin, whereas brown rot fungi only modify lignin during decomposition of cellulose and hemicellulose.

The results of this analysis indicate that the density was $4.13 \%$, the holocellulose was $6.70 \%$, alcohol-benzene extractive was $0.84 \%$, hot-cold water extraction was $4.20 \%$, and the $1 \% \mathrm{NaOH}$ alkali solubility was $9.80 \%$. However, the lignin analysis result did not change. Pleszczyńska et al. (2017) reported that brown-rot fungus extensively degrades the carbohydrate fraction of lignocellulose, but in contrast to white-rot fungi, it leaves lignin, although in a modified form. 
Table 3. Chemical Compounds of Betula pendula

\begin{tabular}{|l|c|c|}
\hline Chemical Compounds of Betula pendula & Holocellulose (\%) & Lignin (\%) \\
\hline Literature Results ${ }^{*}$ of Betula pendula & 85.13 & 17.15 \\
\hline Control Wood & 83.96 & 16.50 \\
\hline Degraded Wood & 77.26 & 16.50 \\
\hline Mass Loss Percent (\%) & 6.70 & 0.00 \\
\hline
\end{tabular}

* Cabalova et al. (2017)

Fackler et al. (2010) have investigated spruce wood that has decomposed by brownrot fungi (Gloeophyllum trabeum or Poria placenta) in the laboratory. According to results, mass losses up to $16 \%$ were observed, and the affected material was explored by transmission Fourier transform infrared (FT-IR) imaging microscopy. It was found that the degradation led to a mass loss at the ML layer.

Table 3 illustrates the cellulose content variation of the wood cells. These cells belonged to $B$. pendula that suffered from white-rot fungus and brown-rot fungus. With two-fold replication, birch wood was decomposed for $0,4,8$, and 12 weeks by the whiterot fungus, Phlebia tremellosus, and for 12 weeks by 6 other white-rot and brown rot fungi. White-rot fungus ( $P$. tremellosus) caused progressive weight losses and increases in the $\mathrm{H}$ $\mathrm{C}$ and $\mathrm{O}-\mathrm{C}$ ratios of the residue wood by preferentially degrading the lignin (Hedges et al. 1988). White rot fungus degraded only the lignin in the birch wood.

In addition, the cellulose content variation in the heartwood fibers are shown in Table 3. Further research about B. pendula wood and Piptoporus betulinus fungus could contribute to better exploitation of the wood-based products application potential. Brown rot started to attack the outer cell wall regions, which are the middle lamellae, P, and S1 layers. Here the P symbol indicates the primary cell wall. S1 symbol indicates the external sheet of the secondary cell wall. This is shown in the determination of mass loss in wood (Arantes et al. 2012).

\section{CONCLUSIONS}

1. Betula pendula did not exhibit any change in the lignin analysis results according to the chemical analysis results of wood. Therefore, fungus did not disturb the lignin structure of $B$. pendula wood. In the $B$. pendula wood, fungus consumed cellulose. Thus, the mass loss of holocellulose of wood was $6.70 \%$. Therefore, the strength and quality values of wood decreased. It follows that imported woods that are biodegraded by fungus cause a serious economic loss in wood-based products.

2. Brown rot fungus reduced mass loss resistance in Betula pendula wood, resulting in a loss of density by $14.1 \%$. The content of substances analyzable in $1 \% \mathrm{NaOH}$ (alkaline solution) in $B$. pendula wood was $9.8 \%$. Mass loss reduction caused a decrease in strength in $B$. pendula wood. Brown rot fungi in $B$. pendula are responsible for the reduction of all strength values by breaking wood cellulose bonds.

\section{ACKNOWLEDGMENTS}

This study was supported by Kastamonu Entegre Ağaç Sanayi. The author would 
like to acknowledge the Division of Wood Chemistry and Technology Department and the Faculty of Forestry at Duzce University for their support.

\section{REFERENCES CITED}

Arantes, V., Jellison, J., and Goodell, B. (2012). "Peculiarities of brown-rot fungi and biochemical Fenton reaction with regard to their potential as a model for bioprocessing biomass," Appl. Microbiol. Biotechnol. 94, 323-338. DOI: 10.1007/s00253-012-3954-y.

Arantes, V., and Goodell, B. (2014). "Current understanding of brown-rot fungal biodegradation mechanisms: A review," in: Deterioration and Protection of Sustainable Biomaterials, T. P. Schultz, B. Goodell, and D. D. Nicholas (eds.), ACS Publications, American Chemical Society: Washington, DC, USA, pp. 3-21. DOI: 10.1021/bk-2014-1158.ch001

Baldrian, P., and Gabriel, J. (2002). "Intraspecific variability in growth response to cadmium of the wood-rotting fungus Piptoporus betulinus," Mycologia 94(3), 428436. DOI: 10.1080/15572536.2003.11833208

Baldrian, P., and Valaskova, V. (2008). "Degradation of cellulose by basidiomycetous fungi," FEMS Microbiology Reviews 32(3), 501-521. DOI: 10.1111/j.15746976.2008.00106.x

Bell, M. K., and Burnett, J. H. (1966). "Cellulase activity of Piptoporus betulinus," Annals of Applied Biology 58(1), 123-130. DOI: 10.1111/j.17447348.1966.tb05077.x

Boddy, L. (2001). "Fungal community ecology and wood decomposition processes in angiosperms: From standing tree to complete decay of coarse woody debris," Ecological Bulletins 49, 43-56.

Cowling, E. B. (1961). "Comparative biochemistry of the decay of sweetgum sapwood by white-rot and brown-rot fungi," USDA Forest Service, Washington, DC Technical Bulletin-1258

Curling, S. F., Clausen, C. A., and Winandy, J. E. (2002). "Relationships between mechanical properties, weight loss, and chemical composition of wood during incipient brown-rot decay," Forest Product Journal 52, 34-39.

Hedges, J. I., Blanchette, R A., Weliky, K., and Devol, A. H. (1988). "Effects of fungal degradation on the $\mathrm{CuO}$ oxidation products of lignin: A controlled laboratory study," Geochimica et Cosmochimica Acta. 52(11), 2717-2726. DOI: 10.1016/00167037(88)90040-3

Henningsson, B. (1965). "Physiology and decay activity of the birch conk fungus Piptoporus betulinus (Bull.)," Fr. Studia Forestalia Suecica Nr 34. Skogshögskolan [Faculty of Forestry, Swedish University of Agricultural Sciences N 34], Stockholm, Sweden.

Hynynen, J., Niemistö, P., Vihera-Aarnio, A., Brunner, A., Hein, S., and Velling, P. (2010). Silviculture of birch (Betula pendula Roth and Betula pubescens) in northern Europe," Forestry: An International Journal of Forest Research 83(1), 103-119. DOI: 10.1093/forestry/cpp035

Cabalova, I., Zachara, M., and Tomanb, B. (2017). "Characterization of thermally loaded woods species in the view of physical-chemical and fire technical properties," in: International Scientific Conference Fire Protection, Safety and Security 2017, 
Zvolen, Slovak Republic pp. 22-36.

Çakıroğlu, E. O., Demir, A., and Aydın, I. (2011). "Comparison of birch and beech wood in term of economic and technological properties for plywood manufacturing," Drvna Industrija: Znanstveni Casopis za Pitanja Drvne Tehnologije 70(2), 169-174. DOI: 10.5552/drvind.2019.1828

Fackler, K., Stevanic, J., Ters, T., Hinterstoisser, B., Schwanninger, M., and Salmen, L. (2010). "Localisation and characterisation of incipient brown-rot decay within spruce wood cell walls using FT-IR imaging microscopy," Enzyme and Microbial Technology 47(6), 257-267. DOI: 10.1016/j.enzmictec.2010.07.009.

Fackler, K., and Schwanninger, M. (2012). "How spectroscopy and microspectroscopy of degraded wood contribute to understand fungal wood decay," Applied Microbiology and Biotechnology 96(3), 587-599. DOI: 10.1007/s00253-012-4369-5

Faix, O., Bremer, J., Schmidt, O., and Stevanovic T. J. (1991). "Monitoring of chemical changes in white-rot degraded beech wood by pyrolysis - gas chromatography and Fourier-transform infrared spectroscopy," Journal of Analytical and Applied Pyrolysis. 21(1-2), 147-162. DOI: 10.1016/0165-2370(91)80022-Z

Gilbertson, R. L. (1980). "Wood-rotting fungi of North America," Mycologia 72(1), 1-49.

Heräjärvi, H. (2001). "Technical properties of mature birch (Betula pendula and B. pubescens) for saw milling in Finland," Silva Fennica 35(4), Article ID 581. DOI: $10.14214 / \mathrm{sf} .581$

Irbe, I., Andersons, B., Chirkova, J. Kallavus, U., Andersone, I., and Faix, O. (2006). “On the changes of pinewood (Pinus sylvestris L.) chemical composition and ultrastructure during the attack by brown-rot fungi Postia placenta and Coniophora puteana," International Biodeterioration \& Biodegradation 57, 99-106.

Karayılmazlar, S., Saraçoğlu, N., Çabuk, Y., and Rıfat, K. (2011). "Utilizations of biomass as an energy source in Turkey," Bartın University, Bartın Faculty of Forestry, Department of Forest Industry Engineering, Bartın Faculty of Forestry Journal 13(19), 63-75. ISSN: 1302-0943. EISSN: 1308-5875. 74100 / Bartın.

Kahl, T., Arnstadt, T., Baber, K., Bässler, C., Bauhus, J., Borken, W., and Gossner, M. M. (2017). "Forest ecology and management wood decay rates of 13 temperate tree species in relation to wood properties, enzyme activities and organismic diversities," Forest Ecology and Management, 391, 86-95.

Kubicek, C. P. (2013). Fungi and Lignocellulosic Biomass, John Wiley \& Sons, Inc., India.

Lachowicz, H., Wroblewska, H., Sajdak, M., Komorowicz, M., and Wojtan, R. (2019). "The chemical composition of silver birch (Betula pendula Roth.) wood in Poland depending on forest stand location and forest habitat type," Cellulose 26, 3047-3067. DOI: $10.1007 / \mathrm{s} 10570-019-02306-2$.

Lafuze, H. H. (1937). "Nutritional characteristics of certain wood destroying fungi, Polyporus betulinus Fr., Fomes pinicola (Fr.) Cooke, and Polystictus versicolor Fr," Plant Physiology 12(3), 625-646. DOI: 10.1104/pp.12.3.625.

Monrroy, M., Ortega, I., Rmirez, M., Baeza, J., and Freer, J. (2001). "Structural change in wood by brown rot fungi and effect on enzymatic hydrolysis," Enzyme and Microbial Tecnolgy 49(5), 472-477.

Mohebby, B. (2003). Biological Attack of Acetylated Wood, Ph.D. Dissertation, Göttingen University, Germany.

Pleszczyńska, M., Lemieszek, M. K., Siwulski, M., Wiater, A., Rzeski, W., and Szczodrak, J. (2017). "Fomitopsis betulina (formerly Piptoporus betulinus): The 
Iceman's polypore fungus with modern biotechnological potential," World Journal of Microbiology and Biotechnology 33(5), Article number 83. DOI: 10.1007/s11274017-2247-0

Rayner, A, D, M., and Boddy, L. (1988). Fungal Decomposition of Wood - Its Biology and Ecology, John Wiley \& Sons Inc., UK.

Schmidt, O. (2006). Wood and Tree Fungi: Biology, Damage, Protection, and Use, Springer- Verlag, Germany.

Schmidt, O., Gaiser, O., and Dujesiefken, D. (2012). "Molecular identification of decay fungi in the wood of urban trees," European. Journal of Forest Research 131, 885891.

Song, Z., Vail, A., Sadowsky, M. J., and Schilling, J. S. (2012). "Competition between two wood-degrading fungi with distinct influences on residues," FEMS Microbiology Ecology 79(1), 109-117, DOI: 10.1111/j.1574-6941.2011.01201.x

TAPPI T203 cm-99 (1999). “Alpha-, beta- and gamma-cellulose in pulp,” TAPPI Press, Atlanta, GA, USA.

TAPPI T204 om-88 (2002). "Alcohol-benzene solubility of wood," TAPPIPress, Atlanta, GA, USA.

TAPPI T207 cm-99 (1999). "Hot- cold solubility of pulp,” TAPPI Press, Atlanta, GA, USA.

TAPPI T211 om-02 (2002). "Ash in wood, pulp, paper and paperboard: Combustion at $525^{\circ} \mathrm{C}$," TAPPI Press, Atlanta, GA, USA.

TAPPI T212 om-02 (2002). "1\% $\mathrm{NaOH}$ solubility of wood and pulp," TAPPI Press, Atlanta, GA, USA.

TAPPI T222 om-11 (2006). “Acid-insoluble lignin in wood and pulp,” TAPPI Press, Atlanta, GA, USA.

TAPPI T257 cm 02 (2012). "Sampling and preparing wood for analysis," TAPPI Press, Atlanta, GA, USA.

TS EN 323 (2008). "Wood-based panel determination of density," TSE, Ankara, Turkey.

TSE TS 2471 (2005). "Wood, determination of moisture content for physical and mechanical test," TSE, Ankara, Turkey.

Ujang, S. (1993). "Decay resistance of Acacia mangium heartwood against brown-and white-rot fungi: Preliminary results," Journal of Tropical Forest Science 6(1), 16-20.

Ujangr, S., Wongz, A. H. H., and Jones, E. B. G. (2007). Wood Degrading Fungi, Mushroom Research Centre, University of Malaya and Ministry of Natural Resources and Environment Malaysia.

Valaskova, V., and Baldrian, P. (2006). "Degradation of cellulose and hemicelluloses by the brown rot fungus Piptoporus betulinus production of extracellular enzymes and characterization of the major cellulases," Microbiology 152(12), 3613-3622. DOI: 10.1099/mic.0.29149-0.

Van der Wal, A., Ottosson, E., and De Boer, W. (2015). "Neglected role of fungal community composition in explaining variation in wood decay rates," Ecology 96, 124-133.

Wise, L. E., Murphy, M., and D'Addieco, A. A. (1946). "Chlorite holocellulose: Its fractionation and bearing on summative wood analysis and on studies on the hemicelluloses," Paper Trade Journal 122(2), 35-43.

Wong, A. H. H., and Wilkes, J. (1988). "Progressive changes in cell wall components of Pinus radiata during decay," International Biodeterioration 24, 481-487.

Zabel, R. A., and Morrell, J. J. (1992). Wood Microbiology, Academic Press, New York. 
Article submitted: April 29, 2019; Peer review completed: April 10, 2020; Revised version received and accepted: April 13, 2020; Published: April 23, 2020. DOI:

10.15376/biores.15.2.4353-4361

\section{NOTES REGARDING POST-PUBLICATION EXPANSION OF ARTICLE}

This item was first published by BioResources on April 23, 2020 as a Pee- Reviewed Brief Communication. Subsequently, the author contributed substantially more content, so the status was changed to Peer-Reviewed Article (Editor's decision on June 22, 2020). No significant changes were made to the original parts of the text. New contents in the republished version include the following:

- Paragraph on first page starting with "The biological degradation..."

- Paragraph on first page starting with "The first attack by..."

- Paragraph on second page starting with "Cellulose is the basic... "

- The final section of the next paragraph on the second page, starting with the words "Fagus sylvatica L. (beach)..."

- The final section of the next paragraph on the second page, starting with the words "Pine sap-wood blocks..."

- The final section of the paragraph on the second page starting with the words "Lachowicz et al. ..." The new material starts with the words "They suggested..."

- Paragraph on the second page starting with the words "Higher Basidiomycota ..."

- Paragraph on the third page starting with the words "The work of Valaskova..."

- Paragraph of the fourth pages starting with "Ujangr et al...."

- The last sentence in a paragraph on the seventh page starting with "The difference between." The added sentence was "Curling et al. (2002) reported that the changes cause important losses in mechanical properties before measurable weight loss can be detected."

- Then a new paragraph was added, as follows: "Fungus consumed only holocellulose in B. pendula wood. Brown rot fungi are important well-defined groups cellulose-degrading fungi (Arantes and Goodell 2014). Piptoporus betulinus is a general wood rotting fungus parasitic for birch (Betula species). İt gives rise to fast mass loss of birch wood or other lignocellulose substrates (Valaskova and Baldrian 2006)."

- The sentences after Table 2, "As shown in Table 2, fungi could reduce mass loss resistance in Betula pendula wood percent $10 \%$. This reduction indicates capability of the fungi to attack wood aggressively. According to Kubick (2013), separated ether bonds in cellulose are liable for decreases in strength."

- The sentence at the bottom of the eight page, "Boddy (2001) reported that white rot fungi are the only organisms known to be able to completely decompose lignin, whereas brown rot fungi only modify lignin during decomposition of cellulose and hemicellulose."

- On the ninth page, the sentences "Fackler et al. (2010) have investigated spruce wood that has decomposed by brown-rot fungi (Gloeophyllum trabeum or Poria placenta) in the laboratory. According to results, mass losses up to $16 \%$ were observed, and the affected material was explored by transmission Fourier transform infrared (FT-IR) imagery microscopy. It was found that the degradation led to a 
mass loss at the ML layer."

- In the next paragraph on the ninth page, the following text: "With two-fold replication, bitch wood was decomposed for $0,4,8$, and 12 weeks by the white-rot fungus, Phlebia tremellosus, and for 12 weeks 6 other white-rot and brown rot fungus. White-rot fungus ( $P$. tremellosus) caused progressive weight losses and increases in the $\mathrm{H}-\mathrm{C}$ and $\mathrm{O}-\mathrm{C}$ ratios of the residue wood by preferentially degrading the lignin (Hedges et al. 1988). White rot fungus degraded only the lignin in the birch wood."

- To the last paragraph in the Results and Discussion section, the following sentences were added: "Brown rot started to attack important in the outer cell wall regions, which are the middle lamellae, P, and S1 layers. Here the P symbol indicates the primary cell wall. S1 symbol indicates the external sheet of the secondary cell wall. This is shown in the determination of mass loss in wood (Arantes et al. 2012)."

- The following text was added as a final paragraph in the Conclusions section: Brown rot fungus reduced mass loss resistance in Betula pendula wood, resulting in a loss of density by $14.1 \%$. The content of substances analyzable in $1 \% \mathrm{NaOH}$ (alkaline solution) in Betula pendula wood was 9.8\%. Mass loss reduction caused the Betula pendula wood to decrease its strength values. Brown rot fungi in Betula pendula are responsible for the reduction of all strength values by breaking wood cellulose bonds.

In addition, the number of cited articles has been more than doubled compared to when the item was published initially as a peer-reviewed brief communication. 